Ingrid Paoletti, Maria Pilar Vettori,

Dipartimento di Architettura, Ingegneria delle Costruzioni e Ambiente Costruito, Politecnico di Milano, Italia

ingrid.paoletti@polimi.it mariapilar.vettori@polimi.it
«Perché un luogo ci impressioni, bisogna che sia fatto di tempo oltre che di spazio - di passato, di storia, di cultura» (Sciascia, 1987).

Larchitettura è tra le tante discipline che, sulla base della loro natura eteronoma, aspirano a rappresentare il futuro, il presente e il passato di una collettività. Così come costruire edifici non costituisce solo una risposta a un bisogno bensì incorpora la traduzione concreta di desideri e aspirazioni, anche la musica, la filosofia, le arti figurative, riflettono, nel loro evolvere, i temi della contemporaneità. La frammentazione delle competenze, la specializzazione dei saperi, la rapida modificazione degli strumenti di lavoro, la digitalizzazione e l'ipersviluppo della comunicazione, sono fenomeni che incidono in modo sostanziale sull'evoluzione delle discipline in una reciproca interazione con i valori immateriali di una comunità - economici, sociali e culturali - e gli assetti materiali dei luoghi in cui essa si esprime.

In unaccezione di eteronomia quale condizione in cui l'azione non è guidata da un principio autonomo e intrinseco alla disciplina bensì determinata dall'interazione con fattori esterni, una riflessione teorica sull'evoluzione degli strumenti del sapere e del fare, ha il compito di definire possibili scenari in grado di fronteggiare il rischio di perdita di una capacità di sintesi delle relazioni tra le condizioni che definiscono l'identità dell'architettura stessa. La sfida della complessità si fonda su mutazioni sociali, tecnologiche e ambientali: una sfida che coinvolge lo spazio, risorsa materiale, nella sua la scala globale e nella sua misura umana; e il tempo risorsa immateriale, oggi valutato in termini di velocità e flessibilità, ma anche di durata e permanenza. Tali elementi incidono sul progetto inteso nella sua unità, quale sintesi di conoscenze molteplici che, data la loro costante evoluzione, viene

\section{HETERONOMY OF ARCHITECTURE. BETWEEN HYBRIDATION AND CONTAMINATION OF KNOWLEDGE}

sottoposto a un confronto continuo.

Il dibattito culturale ha ampiamente indagato il tema dell'arte che deve votarsi all'eteronomia pur conservando la necessità dell'autonomia estetica. Il rischio di dimenticare il proprio statuto ontologico, di perdere la propria identità nella frammentazione e nell'entropia della contemporaneità trova risposta nell'idea di progetto come sintesi tra idea artistica e condizioni ambientali e sociali configurandosi come elemento in grado di coniugare le antitetiche spinte verso una visione autonoma dell'opera, da un lato, e una eteronoma legata ai caratteri geografici, culturali, sociologici e psicologici, dall'altro.

Nell'operare sistemico e corale proprio di discipline come il cinema, la musica ma anche le arti visive o la filosofia, l'atto del progettare è l'espressione della relazione con una comunità di individui le cui azioni si basano su un ruolo sociale oltre che tecnico in quanto agiscono su valori, materiali e immateriali di carattere pubblico.

Se già le scienze, come dimostrò Thomas Kuhn con i suoi scritti sulle rivoluzioni scientifiche, non possono essere comprese senza la loro dimensione storica, discipline come quelle affrontate in questo Dossier rappresentano fenomeni culturali comprensibili appieno solo quando messi in relazione con la cultura del proprio tempo e con i molteplici fattori che le hanno alimentate. Tuttavia, esattamente come dimostrato dalle teorie di Kuhn (Kuhn, 1987), anche la loro evoluzione vive di "rivoluzioni scientifiche" momenti di rottura in grado di modificare l'atteggiamento della comunità nei confronti della disciplina stessa e soprattutto dei propri paradigmi.

Musica, cinema, arte, architettura, filosofia, sono espressioni di ciò che è umano nella sua complessità: divise e rinchiuse nei pro- of a community - economic, social and cultural - as well as the material assets of the places where it expresses itself. Interpreting heteronomy as a condition in which an action is not guided by an autonomous principle that is intrinsic to the discipline, but rather determined by its interaction with external factors, a theoretical reflection on the evolution of the tools of knowledge and creation has the task of defining possible scenarios capable of tackling the risk of losing an ability to synthesise the relationships between the conditions that define the identity of architecture itself.

The challenge of complexity is rooted in social, technological and environmental shifts: a challenge that involves space, a material resource, in its global scale and its human measure; and time, an immaterial resource, nowadays evaluated in terms of speed and flexibility, but also duration and per- manence. These elements impact upon the project as a whole, as a combination of multiple forms of knowledge which, given their constant evolution, is subject to continuous comparison.

The cultural debate has investigated at length the topic of art being forced to devote itself to heteronomy whilst also retaining a need for aesthetic autonomy. The risk of forgetting its own ontological status, of losing its own identity in the fragmentation and entropy of the contemporary world, finds an answer in the idea of design as a synthesis between an artistic idea and the social and environmental conditions in which it is places, configuring itself as an element capable of reconciling the antithetical drives towards an autonomous vision of the work, on the one hand, and a heteronomous one linked to its geographical, cultural, sociological and psychological characteristics, on the other. 
pri ambiti disciplinari non sono in grado di esprimere la qualità poetica della vita e quindi «far sentire e far prendere coscienza del sentimento estetico» (Morin, 2019).

Emanuele Coccia, filosofo di fama internazionale, professore associato presso la École des hautes études en sciences sociales (EHESS) a Parigi, immagina un mondo in cui tutto ciò che vedete è il prodotto di una intenzionalità articolata da attori umani, non umani e non viventi. Il disegno non solo antropocerntrico è il potere più universale del mondo. Ogni essere vivente può - di fatto - progettare il mondo, ma al contempo anche ogni agente di materia può progettare e l'interplay di questi elementi crea una metamorfosi continua del nostro ambiente. Non è necessario essere vivi per essere un designer. I due antropologi, Alfred Gell e Philippe Descola nei loro scritti relativa proprio alla società occidentale e alla natura riportano una visione in contrasto sulla presenza dellanima/animismo in natura. Ne consegue una sorta di architettura del paesaggio, dove la natura stessa viene riconosciuta come intenzionalità progettuale in un continuum con gli esseri umani.

Edoardo Tresoldi, giovane scultore italiano, è uno dei nuovi esponenti dell'Eteronomia dell'architettura che rifugge i confini limitanti delle discipline per immaginare una visione trasversale dell'ambiente e della sua costruzione. Tresoldi, infatti, tramite un gioco di trasparenze realizzato con strutture effimere di metallo esalta la geometria di questa materia prima, andando al di là della semplice dimensione spazio-temporale per giungere ad un dialogo tra luogo e sua rappresentazione artistica. Tresoldi ci racconta questo suo percorso attraverso 5 tematiche: il Luogo, perché l'architettura di per sè risulta fortemente condizionata dal contesto e nel suo caso anche l'arte; il Progetto, cioè l'atto

In the systemic and concerted working process so intrinsic to disciplines such as filmmaking and music - but also the visual arts or even philosophy - the act of designing is the expression of the relationship with a community of individuals whose actions are based on a role that is as social as it is technical, given that they act based on material and immaterial values of a public nature.

If indeed the sciences - as Thomas Kuhn demonstrated in his writings on the scientific revolutions - cannot be understood without their historical dimension, then disciplines such as those addressed in this Dossier represent cultural phenomena that can only truly be understood in their entirety when considered in the context of their era and the many factors that fed into their creation. However, precisely as demonstrated by Kuhn's theories (Kuhn, 1987), their evolution also consists of "scientific revolutions": mo- ments of disruption capable of changing the community's attitude towards the discipline itself and, perhaps more importantly, its paradigms.

Music, cinema, art, architecture and philosophy are all expressions of that which makes us human, in all its complexity: divided and confined to their own disciplinary fields, they are not capable of expressing the poetic quality of life and thus «making people feel and become aware of the aesthetic feeling» (Morin, 2019).

Emanuele Coccia, an internationally renowned philosopher and associate professor at the École des Hautes Études en Sciences Sociales in Paris, imagines a world in which everything you see is the product of an intentionality articulated by human, nonhuman and non-living actors. Design - not only anthropocentric design - is the most universal power in the world. Every living being can, in effect, design

di prefigurazione dell'opera che risulta influenzato da ciò che ci circonda e dalla nostra immaginazione; il Tempo, in quanto l'arte è caratterizzata da un possibile intreccio, una continuità nei processi creativi influenzati dalla storia del luogo; la Materia, o meglio la materialità e il dualismo tra parte tecnica e artistica; e infine il "What's Next", inteso come quello che ci riserva il futuro. Su questo punto Tresoldi immagina un'ulteriore apertura delle sue opere a competenze diversificate che creino anche nuovi profili professionali nei giovani.

Cristina Frosini, Direttore del Conservatorio di Milano, con un contributo sulla musica, «supremo mistero delle scienze dell'uomo» (Lévi-Strauss, 2004) apre la riflessione su un campo dalle profonde affinità con la disciplina architettonica, accomunate dalla forte relazione tra composizione ed esecuzione. La vastità dell'espressione musicale, dalla precisione dello spartito di musica classica alla libertà di interpretazione del direttore d’orchestra o dell'improvvisazione del jazz, vede nei concetti di ritmo e melodia dell'insieme, omogeneità e identità di diversi strumenti, circolarità del processo, i temi della musica intesa come arte pubblica il cui processo creativo si fonda da sempre sulla relazione tra fattori tecnici e fattori culturali.

Il contributo di Michele Guerra, studioso e docente di storia del cinema, conferma quanto già testimoniato da Edgar Morin. «Ormai, il cinema è pienamente riconosciuto come arte e a mio parere è una grandissima arte polifonica e polimorfa, che può stimolare e integrare in sé le virtù di tute le altre arti, romanzo, teatro, musica, pittura, scenografia, fotografia. [...] si può dire che coloro che partecipano allelaborazione di un film, sono artigiani, artisti, che svolgono un ruolo importante nell'estetica del film» (Morin, 2019). Il "cantiere cinematografico" opera sulla

the world, but at the same time, every agent of matter can also design, and it is the interplay between these elements that creates a continuous metamorphosis of our environment. In other words, being alive is not a necessary condition for being a designer. The two anthropologists Alfred Gell and Philippe Descola, in their writings on Western society and nature, present contrasting views on the presence of the soul/animism in nature. The result is a sort of architecture of the landscape, in which nature itself is imbued with a sense of design intentionality that exists in a continuum with mankind.

Edoardo Tresoldi, a young Italian sculptor, is one of the latest exponents of the heteronomy of architecture, which rejects the limiting confines of individual disciplines so as to imagine a transversal vision of the environment and its construction. Through the in- terplay of transparencies created with ephemeral metal structures, Tresoldi exalts the geometrical qualities of this raw material, going beyond the simple spatiotemporal dimension to establish a dialogue between place and the artistic representation thereof. Tresoldi recounts this journey of his through five themes: Place, because architecture in itself is markedly conditioned by its context, as is - in his case - art; Design, that is the act of envisaging the work, which is ultimately influenced by everything around us and our imagination; Time, as art is characterised by a potential interweaving, a continuity in the creative processes influenced by the history of the place; Material, or rather, materiality and the duality between the technical and artistic parts; and, finally, "What's Next", exploring the idea of what the future holds for us. On this last point, Tresoldi imagines his works further opening up to a 
spinta di forze che, incorporando l'attualità dei fattori tecnici e materiali, conducono ad "un'idea di metamorfosi immaginaria" che rispecchi le aspirazioni di una società nel suo farsi contemporanea.

Un concetto di approccio eteronomo al "fare" si fonda anche sul riconoscimento del valore didattico dell'opera, come emerge dal contributo di Luigi Alini sulla figura di Vittorio Garatti, intellettuale ancora prima che architetto la cui opera è frutto di lavoro immateriale quanto materiale, in una logica «esperienziale e non mediatica» (Frampton, in Borsa and Carboni Maestri, 2018), come la vera architettura è chiamata ad essere.

Leteronomia dell'architettura, come di altre discipline affini, si fonda su un duplice confronto: la comprensione degli scenari internazionali e la definizione dello statuto del progetto, allo scopo di conformarlo in modo che prenda atto delle modificazioni, operi in continuità e la valorizzazione della storia, in sintonia con l'universalità di una disciplina e l'insegnamento dei suoi maestri.

Stimolare un dialogo tra differenti posizioni culturali significa creare le condizioni per una adesione alla contemporaneità senza rinunciare ad un principio di continuità storica. In quest'ottica il contributo di Ferruccio Resta, attuale rettore del Politecnico di Milano, pone lattenzione sulle differenti posizioni culturali e intellettuali che, nel tempo, hanno animato la cultura politecnica rappresentando un patrimonio di elevato valore. Oggi, dati alcuni postulati irrinunciabili quali sostenibilità e connettività, la tecnologia sembra sopraffare il processo progettuale esportandolo verso una sorta di controllo ingegneristico e di produzione di componenti. Ecco la necessità allora di ribadire una dimensione "umanistica ed umana" del fare, orientando anche i pro-

diversified range of skills in a way that would also carve out new professional profiles for young people.

Cristina Frosini, Director of the Milan Conservatory, with a contribution on music - «the supreme mystery of the sciences of man» (Lévi-Strauss, 2004) - offers reflections on a field with deep affinities with the discipline of architecture, with both sharing a strong relationship between composition and execution. The sheer vastness of musical expression, from the precision of the classical score to the freedom of interpretation exemplified by the conductor or the improvising jazz musician, sees the concepts of overall rhythm and melody, the homogeneity and identity of different instruments, and the circularity of the process as the key themes of music as a public art whose creative process has always been founded upon the relationship between technical factors and cultural factors.
The contribution provided by Michele Guerra, an academic and professor of History of Cinema, confirms the words of Edgar Morin. «Nowadays, cinema is widely recognised as an art, and in my opinion, it is a tremendous polyphonic and polymorphous art that is capable of stimulating and integrating into itself the virtues of all the other arts: novel-writing, theatre, music, painting, scenography, photography. [...] it can be said that those who participate in the creation of a film are artisans, artists, who play an important role in the aesthetics of the film» (Morin, 2019). The work of the "cinematographic construction site" is driven by forces which, incorporating the status quo of the technical and material factors, lead to "an idea of imaginary metamorphosis" which reflects the aspirations of a society in its efforts to become contemporary.

A concept of a heteronomous approach

cessi formativi in linea con le parole dello storico-filosofo Youval Noah Harari, quando afferma: «Molti esperti di pedagogia ritengono che le scuole dovrebbero impostare la didattica sulle "quattro C": critica, comunicazione, collaborazione e creatività. Più in generale le scuole dovrebbero ridurre le conoscenze tecniche specifiche e sviluppare le abilità utili alla vita in generale. La più importante delle quali sarà la capacità di gestire il cambiamento, di imparare nuove cose, e di mantenere il controllo in situazioni di emergenza» (Harari, 2018).

Tale necessità che riapre il tema del dualismo tra "arte" e "disciplina" superandolo in favore di una coesistenza terminologica in quanto è la qualità del progetto e dell'opera che ne definiscono l'appartenenza.

Riflettere sui fondamenti dei percorsi e degli strumenti disciplinari, alla luce delle innovazioni che coinvolgono lo statuto del progetto in termini non solo concettuali bensì anche strumentali significa ragionare sul concetto di "cultura del progetto" inteso come capacità di operare attraverso azioni di sintesi dei differenti apporti affrontando problematiche complesse tramite un processo creativo consapevole.

La capacità di prefigurare il nuovo, come è implicito nella etimologia stessa di progetto, e, al tempo stesso, di interpretare la continuità intesa quale coerenza di metodo e di valori è comune alle discipline e alle competenze riunite nel Dossier: occuparsi di cultura, società, città, paesaggio, ambiente, richiede visione molteplice, capacità di lettura dei problemi ma anche apertura mentale verso le opportunità, governo della complessità, controllo dei rischi di abbassamento della qualità contro concetti di efficienza basati su parametri numerici lomologazione dei linguaggi.

to "making" is also founded upon recognising the didactic value of the work, as emerges from Luigi Alini's contribution on the figure of Vittorio Garatti - an intellectual first and architect second - whose pieces are the result of work that is as much immaterial as it is material, with an «experiential rather than mediatic» approach (Frampton, in Borsa and Carboni Maestri, 2018), as true architecture is expected to be. The heteronomy of architecture, much like that of other similar disciplines, is based on engagement on two fronts: an understanding of the relevant international scenarios and the definition of the project charter, with a view to conforming it so that it takes into account any changes, operates in continuity with and with an appreciation for history, and develops in harmony with the universality of the discipline and the teachings of its masters.

Stimulating a dialogue between dif- ferent cultural positions is a means to create the conditions for a degree of adherence to contemporaneity without compromising on a principle of historical continuity. In light of this, the contribution by Ferruccio Resta - the current Rector of the Politecnico di Milano - focuses on the varying cultural and intellectual positions that have animated the culture of the Politecnico over the years, representing a highly valuable heritage for the university. Nowadays, with the presence of certain indispensable premises such as sustainability and connectivity, technology seems to overwhelm the design process, outsourcing it to a sort of management of the engineering and component production aspects. Hence the need to reaffirm a "humanistic and human" dimension of the act of making, starting at the root by orienting the training processes in line with the words of historian and philosopher Yuval Noah Harari, who 
Dal confronto dei vari contributi e punti di vista emerge un quadro per cui l'importanza delle relazioni, la ricerca di quelle che Eiffell definiva le "segrete leggi dell'armonia", la specificità disciplinare del progetto quale capacità di porsi in relazione "per comprendere, criticare, trasformare" (Gregotti, 1981), la capacità di distinguere il diverso coinvolgendolo nella trasformazione progettuale, rappresentano i fondamenti per l'evoluzione delle discipline eteronome attraverso un superamento delle nozioni di tecnica e di contesto come referenti passivi ma generativi di possibilità in linea con la riflessione rogersiana sulle preesistenze ambientali come condizioni storiche di riferimento assunte criticamente come determinanti. Di qui la validità un approccio culturale "politecnico" in grado di mettere in campo strumenti e competenze in grado di affrontare le condizioni operative proprie di un contesto eteronomo, ma anche in grado di stimolare approcci critici orientati all'innovazione e a gestire il cambiamento in una visione del progetto come occasione, riprendendo le parole di Franco Albini, di «sperimentazione e verifica in relazione al progredire delle tecniche costruttive, degli strumenti di indagine, delle conoscenze nei vari campi e in relazione al mutare della cultura contemporanea» (Albini, 1968).

La necessità di un umanesimo è fortemente collegata alla reintroduzione del concetto di "bellezza", nel suo significato moderno che passa da una valenza soggettiva a una valenza universale. Da qui l'importanza del dialogo con discipline che riconoscono in una matrice politecnica da sempre esprime una profonda attenzione al rapporto tra teoria e prassi, al progetto di architettura come azione al tempo stesso intellettuale e tecnica.

Partendo pertanto dall'assunto che «nessuna teoria può essere portata avanti senza imbattersi in un muro che solo la pratica

says: «Many pedagogical experts argue that schools should switch to teaching "the four Cs" - critical thinking, communication, collaboration, and creativity. More broadly, they believe, schools should downplay technical skills and emphasize general-purpose life skills. Most important of all will be the ability to deal with change, learn new things, and preserve your mental balance in unfamiliar situations».

This need reopens the theme of the dualism between "art" and "discipline", surpassing it in favour of a coexistence of terminology in that it is the quality of the design and the piece that define where it belongs.

Reflecting on the foundations of the paths and tools employed in different disciplines - in light of the innovations that involve the project charter in terms not only of concepts, but also of instruments - means reflecting on the concept of "project culture", un- derstood as the ability to work through actions which combine different contributions, tackling complex problems by way of a conscious creative process. The ability to envisage the new - as is implicit in the etymology of the word "project" itself - and, at the same time, to interpret continuity in the sense of a coherent system of methods and values, is shared by the disciplines and skills brought together in the Dossier: dealing with culture, society, the city, the landscape and the environment all at once requires a multifaceted vision, an ability to read problems, but also a certain openmindedness towards opportunities, the management of complexities, control of the risks of drops in quality in service of concepts of efficiency based on numerical parameters and the standardisation of languages. A comparison of the various contributions and perspectives throws up a picture in which the importance of re- può penetrare» (Deleuze and Foucault 1972; Deleuze, 2002; Foucault, 1977; Deleuze, 2007), è oggi indispensabile promuovere figure di artisti, musicisti, filosofi, architetti umanisti, in grado di governare il progetto come sintesi di fattori esterni ma anche come dialettica interna, nonché competenze in grado di fare di cultura intesa come sapienza tecnica.

Talvolta, nella difficoltà di individuare un'identità delle discipline si cerca di tracciare una frontiera che metta nelle condizioni di capirne il senso e i contenuti. Tuttavia, dai punti di vista emersi nel Dossier appare ancora più importante «lavorare sui confini di ciascun sapere», riprendendo un concetto espresso da Salvatore Veca (Veca, 1979), ponendo al centro la comunicazione tra i campi, interpretando le relazioni e i rapporti, individuando la prospettiva relazionale quale aspetto fondativo del fare.

La posizione dell'architettura quale «arte al confine delle arti» ${ }^{1}$ come in più occasioni ribadito da Renzo Piano, consente una riflessione sulla sua identità ponendola in una posizione non tanto di emarginazione quanto di centralità. Un concetto di "confine" che riprende il punto di vista sociologico che distingue il "limite finito" (boundary) dall'"area di interazione" (border) (Sennet, 2011; Sennet, 2018), in cui avviene il contatto mutevole ma costruttivo con le entità necessarie per la sua attuazione. L'eteronomia dell'architettura coincide con la sua "universalità", un concetto che per Alberto Campo Baeza (Campo Baeza, 2018) rappresenta l'identità dell'architettura. dipendere dalla vita dell'uomo, dallo sviluppo della società, della sua crescita culturale, deriva da un unico e imprescindibile fattore: la sua eteronomia, condizione necessaria ad un processo, artistico quanto tecnico, che deve esprimere i valori di una collettività nel tempo e rappresentare non tanto il "nuovo" quanto il "bello". lationships, the search for what Eiffell defined «the secret laws of harmony», the disciplinary specificity of design as the ability to relate in order to «understand, criticise, transform» (Gregotti, 1981), the ability to distinguish that which is different by involving it in the transformation of design, all represent the foundations for the evolution of heteronomous disciplines in how they move beyond the notions of technique and context as passive referents which generate possibilities in line with the Rogersian reflection on pre-existing environmental elements as historical conditions for reference, critically taken on as determinants.

Hence the validity of a "polytechnic" cultural approach that is not only capable of deploying tools and skills which can deal with the operating conditions to be found in a heteronomous context, but also of stimulating critical approaches oriented towards innovation and managing change with the perspective of a project as an opportunity - in the words of Franco Albini - for "experimentation and verification in relation to the progression of construction techniques, tools for investigation, knowledge in the various fields and in relation to the shifts in contemporary culture» (Albini, 1968)

The need for a sense of humanism is strongly linked to the reintroduction of the concept of "beauty", in its modern meaning, under which it shifts from a subjective value to a universal one. Hence the importance of the dialogue with disciplines that identify with the polytechnic mould - that is, one which has always been deeply attentive to the relationship between theory and practice, to the design of architecture as an action that is at once intellectual and technical.

As such, starting from the assumption that «no theory can be pursued with- 
Una pratica del progetto basata, riprendendo alcuni concetti già da tempo espressi da Edgar Morin, su "contaminazioni necessarie oltre che possibili", sul contributo della "conoscenza come sistema aperto", ma soprattutto mirata ad operare "contro le continuità incapaci di cogliere la dinamica del cambiamento" (Morin, 1974) diviene pertanto occasione di elaborazione teorica sull'identità della disciplina stessa, ponendosi in equilibrio tra la sfera tecnica e quella poetica, ma attuandosi necessariamente nellopera realizzata dando cioè sostanza alle «ragnatele di rapporti intricati che cercano forma» (Italo Calvino).

\section{NOTE}

${ }^{1}$ Intervento di Renzo Piano all'inaugurazione del $152^{\mathrm{mo}}$ Anno Accademico del Politecnico di Milano, 14 ottobre 2014.

\section{REFERENCES}

Albini, F. (1968), "Appunti per il seminario introduttivo", in Albini, F. (Ed.), Problemi didattici di un corso di progettazione, Istituto di Composizione della Facoltà di Architettura del Politecnico di Milano, Milano, Italia.

Borsa, D. and Carboni Maestri, G. (2018), "Architettura, progetto, università. Intervista a Kenneth Frampton", in Belloni, F. and Colonna di Paliano, E. (Eds.), Le scuole di architettura nel teatro del mondo, "Architettura civile" n. 20/21/22, Araba Fenice, Cuneo, Italia.

Campo Baeza, A. (2018), "Rinuncia e Universalità", Milano Arch Week 2018, 23 maggio 2018, Suola di Architettura AUIC del Politecnico di Milano, Milano, Italia.

Deleuze, G. (2007.), L'isola deserta e altri scritti. Testi e interviste 1953-1974, Einaudi, Torino, Italia.

Deleuze, G. (2002), L'Île déserte et autres textes. Textes et entretiens 1953 1974, Éditions de Minuit, Parigi, Francia.

out hitting a wall that only practice can penetrate» (Deleuze and Foucault 1972; Deleuze, 2002; Foucault, 1977; Deleuze, 2007), it is now essential to promote the professional profiles of artists, musicians, philosophers, humanistic architects and so on who are capable of managing design as a synthesis of external factors, but also as an internal dialectic, as well as skills capable of creating culture understood as technical knowledge.

Sometimes, faced with the difficulty of discerning an identity for disciplines, we attempt to draw a boundary that allows us to better understand their meaning and content. However, going on the points of view that have emerged in the Dossier, it seems more important than ever to "work on the boundaries of each field of knowledge», drawing upon a concept expressed by Salvatore Veca (Veca, 1979), making communication between fields a central value, interpreting relationships and connections, identifying the relational perspective as a fundamental aspect of the creative act.

The position of architecture as an "art at the edge of the arts"', as so often posited by Renzo Piano, allows for a reflection on its identity by placing it in a position that centralises rather than marginalises it. A concept of "edge" that touches upon the sociological viewpoint that distinguishes the "finite limit" (boundary) from the "area of interaction" (border) (Sennet, 2011; Sennet, 2018), in which the transformational yet constructive contact with the entities necessary for its realisation takes place. The heteronomy of architecture coincides with its "universality", a concept that Alberto Campo Baeza (Campo Baeza, 2018) believes to represent the identity of architecture itself. Indeed, its dependence upon human life, the development of society, of its

Deleuze, G. and Foucault, M. (1972), "Les Intellectuals et le pouvoir”, L'Arc, n. 49, Aix-en-Provence, Francia, pp. 3-10.

Foucault, M. (1977), “Gli intellettuali e il potere”, in Foucault, M. (Ed.), Microfisica del potere. Interventi politici, Einaudi, Torino, Italia, pp. 107-18.

Gregotti, V. (1987), "La nozione di contesto”, in Casabella n. 465, pp. 9-10.

Harari, Y.N., (2018), 21 lezioni per il XXI secolo, Giunti Editore/Bompiani, Firenze, Milano. Edizione originale: Harari, Y.N., (2018), 21 Lessons for the 21St Century, Giunti Editore/Bompiani, Firenze, Milano, Italia, p. 382.

Kuhn, T.S. (2008), Le rivoluzioni scientifiche, Il Mulino, Bologna, Italia. Edizione originale: Kuhn, T.S. (1987), "What are Scientific Revolutions?", in Kruger, L., Daston, L.J. and Heidelberger, M. (Eds.), The Probabilistic Revolution, The Mit Press, Cambridge, Massachusetts.

Lévi-Strauss, C. (2004), Il crudo e il cotto, tr. It. Il saggiatore, Milano, Italia.

Morin, E. (1974), Il paradigma perduto. Che cosè la natura umana?, Mimesis, Sesto San Giovanni, (MI), Italia.

Morin, E. (2019), Sullestetica, Raffaello Cortina Editore, Milano, Italia. Edizione originale: Laffont, R. (2016), Sur l'ésthetique, La Feltrinelli, Milano, Italia, pp. 68-69, pp. 116-117.

Sciascia, L. (1987), “Io mi ricordo...”, in Sciascia, L. (Ed.), Questo non è un racconto. Scritti per il cinema e sul cinema, Adelphi, Milano, Italia, p. 119.

Sennet, R. (2011), "Boundaries and Borders", in Burdett, R. and Sudjic, D. (Eds.), Living in the Endless City, Londra, Regno Unito, pp. 324-331.

Sennet, R. (2018), Costruire e abitare. Etica per la città, Feltrinelli, Milano, Italia.

Sennet, R. (2018), “The Open City”, in Sennet, R. (Ed.), Building and dwelling. Ethics for the City, Allen Lane, Londra, Regno Unito.

Veca, S. (1979), (Ed. Paci, E.), Il filosofo e la città. Platone, Whitehead, Husserl, Marx, Il Saggiatore, Milano, Italia.

cultural growth, derives from a single and inalienable factor: its heteronomy, the necessary condition for a process as artistic as it is technical, tasked with expressing the values of a community over time and representing the "beautiful" rather than the "new".

A design practice based on - to borrow some concepts already expressed years ago by Edgar Morin - "contaminations that are necessary as well as possible", on the contribution of "knowledge as an open system", but above all, one aimed at working "against the continuities incapable of grasping the dynamics of change" (Morin, 1974), thus becomes an opportunity to develop a theory on the identity of the discipline itself, striking a balance between the technical and poetic spheres, but necessarily materialising in the finished work, lending substance to the «webs of intricate relationships that seek form» (Italo Calvino).
NOTES

${ }^{1}$ Speech by Renzo Piano at the inauguration of the 152nd Academic Year of the Politecnico di Milano, 14 October 2014. 